\title{
Waste Heat Recovery from Gas Turbine Flue Gases for Power Generation Enhancement in a Process Plant
}

\author{
Valerie Eveloy*, Peter Rodgers, Adesola Olufade, Yuyao Wang, and Ali Al Alili \\ Department of Mechanical Engineering, the Petroleum Institute, Abu Dhabi, United Arab Emirates
}

\begin{abstract}
To improve on-site power generation capacity and efficiency in process facilities, the thermal coupling of an industrial gas turbine cycle with a bottoming organic Rankine cycle for power plant flue gas waste heat recovery in a process facility is investigated. Using 1,1,1,3,3-pentafluoropropane (R245fa) as heat carrier in the Rankine cycle, $5.2 \mathrm{MW}$ of additional electric power is generated, enhancing on-site power generation capacity and energy/exergy efficiency by approximately $23 \%$ and $6 \%$, respectively. The overall energy and exergy efficiencies of the waste heat recovery system are estimated at $9 \%$ and $24 \%$, respectively. Primary energy savings of approximately 1.3 million standard cubic feet per day (MMSCFD) of natural gas, or net annual operating expenditure savings of 1.6 million USD, could be realized with the proposed flue gas waste heat recovery system based on subsidized industrial electricity tariffs in the UAE, with 457 tons of avoided $\mathrm{CO} 2$ emissions per year.
\end{abstract}

Keywords: Organic Rankine Cycle, ORC, Waste Heat, Industrial, Gas Turbine, Exergy

\section{Introduction}

Rapid economic and population developments in the past decade have led to a surge in power demand and environmental emissions in the Arabian Gulf. Decentralized industrial electricity production enables power generation in remote areas with substantial savings in infrastructure and fuel transportation, while eliminating power distribution losses. However, in conventional gas power cycles used for on-site industrial power generation, less than $30 \%$ of the fuel energy is typically converted to useful power, with the rest lost essentially through the exhaust flue gases. In addition, gas turbine efficiency decays in high ambient temperatures relative to ISO standard conditions, mainly due to increased compressor work [1]. To reduce domestic fossil fuel consumption and environmental emissions, energy-intensive industrial process facilities have a need for enhanced on-site power generation capacity at improved efficiency. To date, the use of waste heat recycling technologies has generally been limited in the region's process industry. This may have arisen from factors including energy availability and affordability, practical challenges in assessing process plant energy performance and implementing energy efficiency enhancement technologies, and permitting environmental policies [1]. However, recent shortages of natural gas for domestic power generation, volatile fossil fuel prices and environmental concerns are prompting changes in industrial energy production and utilization practices.

Existing industrial gas turbines (GTs) can be thermally coupled with bottoming power cycles and/or waste heat recovery equipment to produce additional power at a higher efficiency. Organic Rankine cycles (ORC) offer several advantages over conventional bottoming steam Rankine cycles, including compactness, flexibility and safety, with lower operating pressure and maintenance requirements [2]. Recent studies have demonstrated their capability to recover thermal energy from distributed, medium-grade (i.e., $250-650^{\circ} \mathrm{C}$ ) sources [3]. In this study, the thermodynamic performance and economic feasibility of retrofitting an existing industrial gas cycle with a bottoming ORC is evaluated as a potential solution to enhance power generation capacity and reduce primary energy consumption in a hydrocarbon process plant.

\footnotetext{
* Corresponding author.
}

E-mail: veveloy@pi.ac.ae

(C) 2016 International Association for Sharing Knowledge and Sustainability

DOI: $10.5383 /$ ijtee.12.01.007 


\section{Waste Heat Recovery System}

The existing power plant is an industrial natural gas turbine power plant operated at a base load and electrical efficiency of 22.2 MW and 26.9\%, respectively [4]. At yearly-average ambient conditions in the United Arab Emirates (i.e., $28.4^{\circ} \mathrm{C}$, $57 \% \mathrm{RH}[5,6])$, the power plant rejects flue gases to the environment at a temperature and combined mass flow of approximately $490^{\circ} \mathrm{C}$ and $113 \mathrm{~kg} / \mathrm{s}$, respectively, representing approximately $58.4 \mathrm{MW}$ of waste heat ideally available relative to the environmental temperature. The existing GT plant is to be thermally integrated with a bottoming organic Rankine cycle (ORC) for power generation capacity and efficiency enhancement, as illustrated in Figure 1. For system safety and operational stability, an intermediate heat transfer fluid (HTF) is used to transfer power plant waste heat rejected in the flue gas heat exchanger (FGHX) to the Rankine cycle working fluid, namely 1,1,1,3,3-pentafluoropropane (R245fa) in the heat recovery vapor generator (HRVG). R245fa and the saturated Rankine cycle T-s diagram are represented in Figure 1(b). In addition, key R245fa properties are listed in Table 1. R245fa is a non-chlorinated, non-ozone depleting hydrofluorocarbon with good heat transfer capability and thermal stability, and low viscosity [7]. Although alternative working fluids could offer higher ORC power output and efficiency, R245fa also offers the advantages of non-flammability, availability and affordability, as R245fa is one of the most widely employed working fluids in commercially-available ORC systems. In addition, Rf245fa condenses above atmospheric conditions (Table 1), which reduces the risk of ambient gas leakage into the heat recovery system. The flue gas temperature at the outlet of the FGHX is controlled to $150^{\circ} \mathrm{C}$ to safeguard heat recovery equipment reliability, resulting in an amount of actually recovered flue gas waste heat of approximately $43 \mathrm{MW}$. R245fa is classified as isentropic based on the slope of its saturated vapor curve (Figure 1(b)). To promote high power output and efficiency, the ORC turbine (ORCT) inlet pressure is set at approximately $2.3 \mathrm{MPa}$, which corresponds to the highest pressure on the fluid saturation vapor curve permitting expansion of the working fluid in the dry region (Figure 1(b)). This pressure is less than $90 \%$ the fluid critical pressure, Pc, to ensure fluid stability. Expansion of $\mathrm{R} 245 \mathrm{fa}$ in the ORC turbine produces additional electrical power. The expanded working fluid is cooled and condensed by water in the condenser, and pumped back to the HRVG.

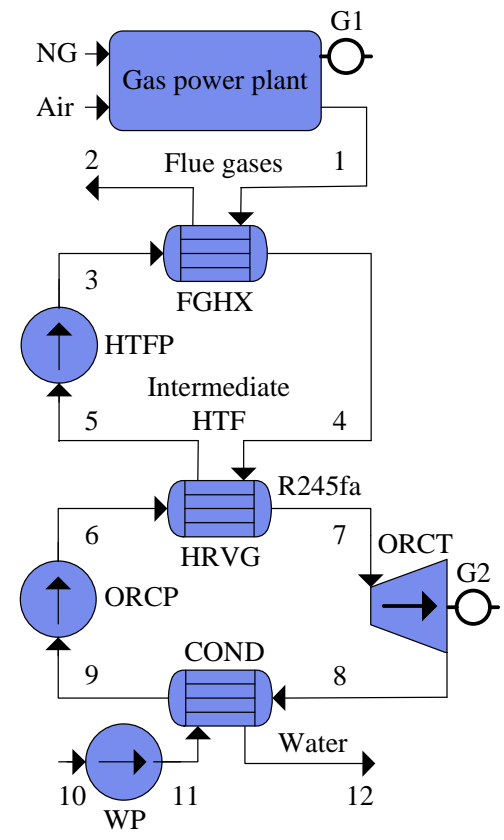

a) Process Flow Diagram

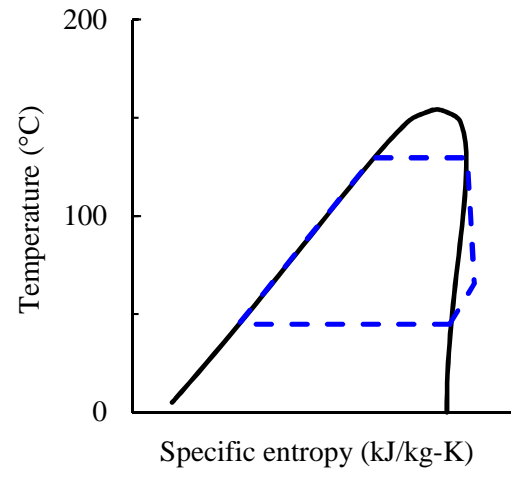

b) R245fa Rankine Cycle T-s Diagram

Note: $\mathrm{COND}=\mathrm{ORC}$ condenser. $\mathrm{HRVG}=$ heat recovery vapor generator. $\mathrm{HTF}=$ intermediate heat transfer fluid. $\mathrm{HTFP}=$ heat transfer fluid pump. $\mathrm{FGHX}=$ flue gas heat exchanger. $\mathrm{NG}=$ natural gas. $\mathrm{ORCP}=\mathrm{ORC}$ pump. $\mathrm{ORCT}=\mathrm{ORC}$ turbine. $\mathrm{WP}=$ water pump.

Figure 1. Compound gas and Rankine cycle power plant

Table 1. R245fa ORC Working Fluid Properties 


\begin{tabular}{ccccccccccc}
\hline $\begin{array}{c}\mathrm{M} \\
(\mathrm{g} / \mathrm{mol})\end{array}$ & $\begin{array}{c}\mathrm{T}_{\mathrm{c}} \\
\left({ }^{\circ} \mathrm{C}\right)\end{array}$ & $\begin{array}{c}\mathrm{P}_{\mathrm{c}} \\
(\mathrm{MPa})\end{array}$ & $\begin{array}{c}\mathrm{L}_{\text {eva }} \text { at } 2.3 \\
\mathrm{MPa}(\mathrm{kJ} / \mathrm{kg})\end{array}$ & $\begin{array}{c}\mathrm{L}_{\text {cond }} \text { at } 45^{\circ} \mathrm{C} \\
(\mathrm{kJ} / \mathrm{kg})\end{array}$ & $\begin{array}{c}\mathrm{C}_{\mathrm{p}, \mathrm{v}} \text { at } 45^{\circ} \mathrm{C} \\
(\mathrm{kJ} / \mathrm{kg}-\mathrm{K})\end{array}$ & $\begin{array}{c}\mathrm{P}_{\text {sat }} \text { at } 45^{\circ} \mathrm{C} \\
(\mathrm{kPa})\end{array}$ & $\mathrm{HH}$ & $\mathrm{PH}$ & $\mathrm{FH}$ & $\mathrm{GWP}$ \\
\hline 134 & 153 & 3.61 & 97.8 & 177.9 & 0.91 & 294.8 & 2 & 1 & 0 & 1,050 \\
\hline
\end{tabular}

Note: Latent heat of evaporation, $\mathrm{L}_{\mathrm{eva}}$, and condensation, $\mathrm{L}_{\mathrm{cond}}$, given at or near the expected evaporation and condensation conditions, respectively. Vapor specific heat capacity, $\mathrm{C}_{\mathrm{p}, \mathrm{v}}$, and saturation pressure, $\mathrm{P}_{\mathrm{sat}}$, given near the expected condensation conditions. $\mathrm{HH}$, FH and PH refer to health, fire and physical hazard classification based on Hazardous Materials Identification System (HMIS) developed by the American Coatings Association. The HMIS rating chart ranges from 0 (minimal hazard) to 4 (severe hazard). GWP refers to global warming potential (100-year) stability [8].

Table 2. Compound gas and Rankine power cycle modeling parameters

\begin{tabular}{lc}
\hline Parameter & Value \\
\hline Environmental & 28.4 \\
Ambient air temperature $\left({ }^{\circ} \mathrm{C}\right)[5]$ & 27.6 \\
Ambient water temperature $\left({ }^{\circ} \mathrm{C}\right)[10]$ & 0.1 \\
Ambient pressure $(\mathrm{MPa})$ & 57 \\
Relative humidity $(\%)[6]$ & $0.79 ; 0.21$ \\
Air molar composition: $\mathrm{N}_{2} ; \mathrm{O}_{2}(-)$ & 22.2 \\
\hline Gas power plant $[4]$ & $0.77 ; 0.13 ; 0.07 ; 0.02$ \\
Net power output at yearly-average ambient conditions, $W_{\text {net, } G T}(\mathrm{MW})$ & 113 \\
Flue gas molar composition: $\mathrm{N}_{2} ; \mathrm{O}_{2} ; \mathrm{H}_{2} \mathrm{O} ; \mathrm{CO}_{2}(-)$ & 490 \\
Flue gas mass flow rate, $\mathrm{m}_{1}(\mathrm{~kg} / \mathrm{s})$ & \\
Flue gas temperature, $\mathrm{T}_{1}\left({ }^{\circ} \mathrm{C}\right)$ & 150 \\
\hline Waste heat recovery system & 2.3 \\
Flue gas temperature at FGHX outlet, $\mathrm{T}_{2}\left({ }^{\circ} \mathrm{C}\right)$ & 1 \\
Organic fluid pressure at turbine inlet, $\mathrm{P}_{7}(\mathrm{MPa})$ & 75 \\
Organic fluid vapor fraction at $\mathrm{HRVG}$ outlet, $x_{7}(-)$ & 80 \\
Pumps' isentropic efficiency $(\%)$ & 10 \\
Organic turbine isentropic efficiency $(\%)$ & 45 \\
Heat exchangers' minimum approach temperature difference, $\Delta \mathrm{T}_{\text {min }}\left({ }^{\circ} \mathrm{C}\right)$ & 0 \\
Organic fluid temperature at condenser outlet, $\mathrm{T}_{9}(-)$ & 3 \\
Organic fluid vapor fraction at condenser outlet, $x_{9}(-)$ & 95 \\
Heat exchanger pressure drop, $\Delta \mathrm{P}(\%)$ & \\
Generator efficiency $(\%)$ & $(\%)$ \\
\hline
\end{tabular}

\section{Thermodynamic Model}

The thermodynamic model of the compound gas and Rankine power cycle is based on mass and energy balances implemented using Aspen software Version 8.4 [9]. The following commonly used assumptions are made:

- Steady state conditions

- Fluid thermo-physical properties are temperature- and pressure dependent

- Air and combustion gases are considered as ideal gas mixtures

- Adiabatic components

- Negligible potential and kinetic energy effects

- No gas leakage

- $\quad$ Pressure drop of $3 \%$ in heat exchangers.

The system modelling parameters are listed in Table 2.

\section{Energy Analysis}

Gas turbine power plant

The GT cycle electrical power output, heat rate, and both exhaust gas mass flow and temperature at yearly- average ambient conditions (Table 2) were derived from manufacturer performance maps [4]. GT electrical efficiency is calculated as:

$$
\eta_{G T}=\frac{\dot{W}_{\text {net,GT }}}{\dot{m}_{f} L H V_{f}}
$$

where $m_{f}$ and $L H V_{f}$ are the mass flow rate and lower heating value of the fuel, respectively.

Waste heat recovery system

The amount of flue gas waste heat that would be dissipated to the atmosphere in abscnce of heat recovery, $Q_{\max , F G H X}$, is estimated as:

$$
\dot{Q}_{\max , F G H X}=\dot{m}_{1}\left(h_{1}-h_{0}\right)
$$

The amount of fluc gas wastc heat that is actually recovered at a vented gas temperature of $150^{\circ} \mathrm{C}, \mathrm{Q}_{F G H X}$, is calculated as:

$$
\dot{Q}_{F G H X}=\dot{m}_{1}\left(h_{1}-h_{2}\right)
$$

where $h_{2}$ is the specific enthalpy of the vented exhaust gas at $150^{\circ} \mathrm{C}$. 
The ORC net power output is given by:

$$
\begin{aligned}
& \dot{W}_{\text {net }, \text { ORC }}=\dot{m}_{7}\left[\left(h_{7}-h_{8}\right)-\left(h_{3}-h_{5}\right)-\left(h_{6}-h_{9}\right)-\right. \\
& \left.\quad\left(h_{11}-h_{10}\right)\right]
\end{aligned}
$$

The overall thermal efficiency of the waste heat recovery system is defined here as the product of the Rankine cycle efficiency and HRVG heat recovery efficiency [11]:

$$
\eta_{F G H X-O R C}=\eta_{F G H X} \eta_{O R C}
$$

where the Rankine cycle efficiency is defined as:

$$
\eta_{\text {ORC }}=\frac{\dot{W}_{n e t, O R C}}{\dot{m}_{7}\left(h_{7}-h_{6}\right)}
$$

and the FGHX heat recovery efficiency is the ratio of the flue gas waste heat actually recovered to the amount of waste heat ideally recoverable [11]:

$$
\eta_{F G H X}=\frac{\dot{Q}_{F G H X}}{\dot{Q}_{\max , F G H X}}
$$

Compound gas and Rankine power plant

The net power output of the compound cycle is evaluated as:

$$
\dot{W}_{n e t, G T-O R C}=\dot{W}_{n e t, G T}+\dot{W}_{\text {net }, O R C}
$$

The compound power cycle energy efficiency is evaluated as:

$$
\eta_{G T-O R C}=\frac{\dot{W}_{\text {net } G T-O R C}}{\dot{m}_{f} L H V_{f}}
$$

\section{Exergy analysis}

The exergy destruction and exergy efficiency of the compound GT-ORC system and its components are evaluated with the dead state at the environmental temperature and pressure $\left(T_{0}, P_{0}\right)$. The general steady-state exergy balance of a control volume is expressed as:

$$
\begin{gathered}
\sum\left(1-\frac{T_{0}}{T_{n}}\right) \\
\dot{E} x_{d}
\end{gathered} \dot{Q}_{n}+\left(\sum_{n} \dot{E} x^{p h, c h}\right)_{\text {in }}=\left(\sum_{n} \dot{E} x^{p h, c h}\right)_{\text {out }}+\dot{W}+
$$

The first and second term on the left hand side of Equation (10) are the exergy transfer rate by heat transfer through the system boundaries and by mass flow at the control volume inlets, respectively. The first term on the right hand side is the exergy transfer rate by mass flow at the control volume outlets, is the rate of exergy transfer by work through the system boundaries, and $x_{\mathrm{d}}$ is the exergy destruction rate.

The exergy of a stream is calculated as the sum of its physical and chemical exergies:

$$
\dot{E} x^{p h, c h}=\dot{E} x^{p h}+\dot{E} x^{c h}
$$

where in absence of potential and kinetic effects, the stream physical exergy is calculated as:

$$
E x^{p h} \approx \dot{m}\left[\left(h-h_{0}\right)-T_{0}\left(s-s_{0}\right)\right]
$$

The fuel chemical exergy is defined as:

$$
\dot{E} x^{c h}=\gamma_{f} \dot{m}_{f} L H V_{f}
$$

where $\gamma_{\mathrm{f}}$ is the fuel exergy grade.

The chemical exergy of a gas mixture is evaluated as:

$$
\dot{E} x_{m i x}^{c h}=\sum y_{i} \dot{E} x_{i}^{c h}+R T_{0} \sum y_{i} \ln y_{i}
$$

The exergy destruction in a steady-state process is the difference between the sums of the exergy flow rates into and out of the system:

$$
\Sigma \dot{E} x_{d}=\Sigma \dot{E} x_{\text {in }}-\Sigma \dot{E} x_{\text {out }}
$$

ORC exergy efficiency is evaluated as:

$$
\varphi_{O R C}=\frac{\dot{W}_{\text {net }, O R C}}{\dot{E} x_{7}^{p h}-\dot{E} x_{6}^{p h}}
$$

The overall exergy efficiency of the waste heat recovery subsystem is defined as:

$$
\varphi_{F G H X-O R C}=\frac{\dot{W}_{\text {net, }, O R C}}{E x_{1}^{p h}-E x_{2}^{p h}}
$$

The exergy efficiencies of the existing gas power plant and compound gas-Rankine cycle are calculated as the ratio of the useful exergy output, which is the net work, to the paid exergy inputs [12], which are the exergies of the feed fuel and air streams:

$$
\varphi=\frac{\dot{W}_{n e t}}{E x_{f}^{p h, c h}+\dot{E x}_{\text {alr }}^{p h}}
$$

\section{Results}

\section{Thermodynamic performance}

The calculated waste heat recovery system performance parameters are summarized in Table 3 for the operating conditions under analysis (Table 2). The sensitivity of the waste heat recovery system performance to ORC turbine inlet pressure up to approximately $90 \%$ of the fluid critical pressure $\left(P_{c}\right)$ is assessed in Figure 2. T-Q diagrams of the heat exchange between the flue gas, intermediate heat transfer fluid and organic fluid in the FGHX and HRVG are shown in Figure 3 at nominal turbine inlet pressure. The exergy destruction distribution in the compound gas-Rankine power cycle is shown is Figure 4. The net power outputs and thermal/exergy efficiencies of the compound power cycle and its components are displayed in Figure 5.

At the operating conditions summarized in Table 2, the ORC provides an additional net power output of $5.2 \mathrm{MW}$, at thermal and exergy efficiencies of approximately $12 \%$ and $57 \%$, respectively (Table 3 ), relative to the existing gas power plant. As indicated in Figure 2, ORC net power output increases monotonically with turbine inlet pressure. However, both the thermal and exergy efficiency of the ORC cycle alone, and overall waste heat recovery system (i.e., FGHX-ORC), display minimal improvement beyond the operating turbine inlet pressure applied (i.e., 2.3 MPa).

The heat recovery efficiency of the flue gas heat exchanger $(\sim 74 \%$, Table 3$)$ is limited by the imposed vented gas temperature. If account is made of the FGHX heat recovery efficiency, the overall waste heat recovery system energy efficiency is approximately 3\% lower than ORC energy efficiency (Table 3 ). The overall waste heat recovery system exergy efficiency indicates that only $24.4 \%$ of the exhaust gas exergy loss in the FGHX is converted to useful power. The specific volume ratio of the working fluid at ORC turbine inlet to outlet (i.e., $\sim 10$ ) is favorable in terms of system size, compared to those for other organic working fluids, such as aromatic hydrocarbons, siloxanes and alkanes, for similar operating conditions. 
Table 3. Waste Heat Recovery System Performance Parameters

\begin{tabular}{ccccccccc}
\hline $\begin{array}{c}\mathrm{T}_{\text {eva }} \\
\left({ }^{\circ} \mathrm{C}\right)\end{array}$ & $\begin{array}{c}\mathrm{W}_{\text {gross,ORC }} \\
(\mathrm{kJ} / \mathrm{kg})\end{array}$ & $\begin{array}{c}\mathrm{W}_{\text {net,ORC }} \\
(\mathrm{MW})\end{array}$ & $\begin{array}{c}\eta_{\text {ORC }} \\
(\%)\end{array}$ & $\begin{array}{c}\eta_{\text {FGHX }} \\
(\%)\end{array}$ & $\begin{array}{c}\eta_{\text {FGHX-ORC }} \\
(\%)\end{array}$ & $\begin{array}{c}\varphi_{\text {ORC }} \\
(\%)\end{array}$ & $\begin{array}{c}\varphi_{\text {FGHX-ORC }} \\
(\%)\end{array}$ & $\begin{array}{c}\left(\rho_{7} / \rho_{8}\right) \\
(-)\end{array}$ \\
\hline 129.7 & 29.4 & 5.2 & 12.0 & 73.6 & 8.8 & 56.7 & 24.4 & 10.1 \\
\hline
\end{tabular}

Note: FGHX = flue gas heat exchanger. $\left(\rho_{7} / \rho_{8}\right)=$ R245fa volumetric expansion ratio at ORC turbine inlet / outlet.

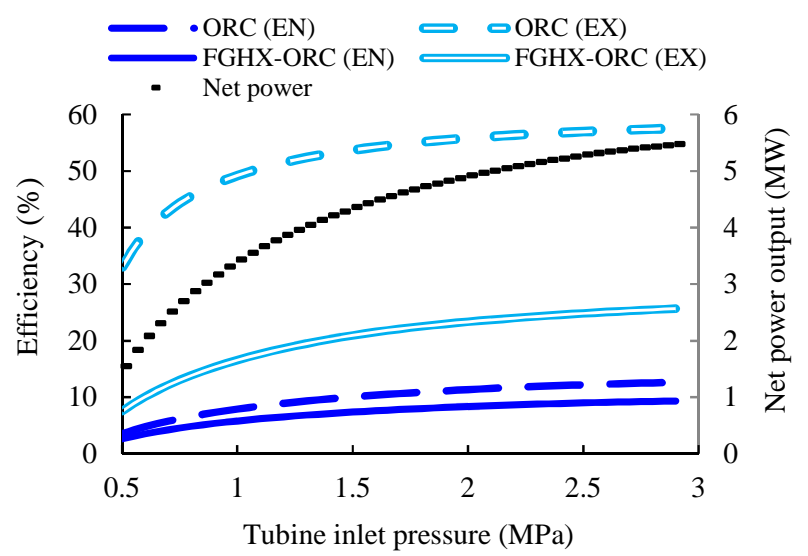

Note: EN and EX refer to energy and exergy efficiency, respectively.

Figure 2. Net Power Output, Energy and Exergy Efficiencies of the ORC and Waste Heat Recovery Sub-System as a Function of ORC Turbine Inlet Pressure

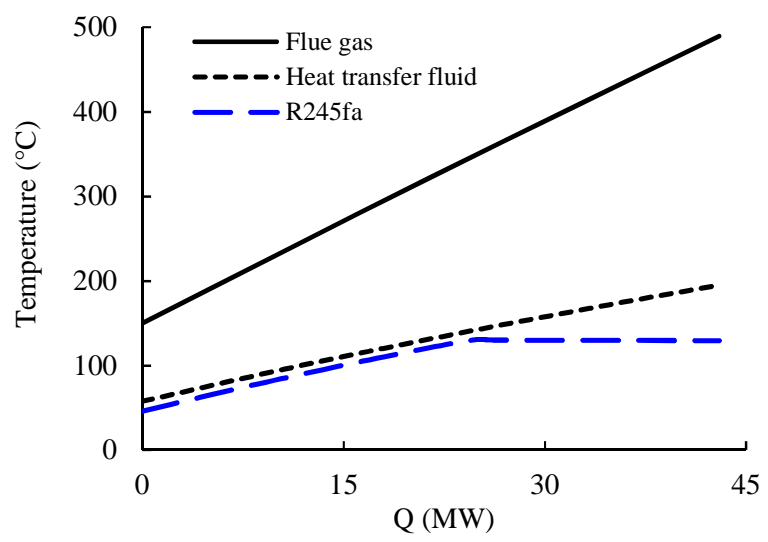

Figure 3. T-Q diagram of Heat Exchange between the Flue Gas, Intermediate Heat Transfer Fluid and Organic Fluid in the FGHX and HRVG 


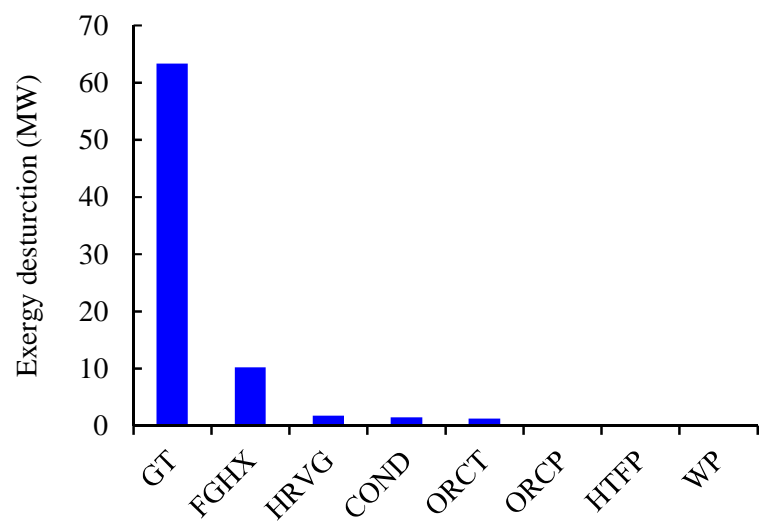

Note: $\mathrm{COND}=\mathrm{ORC}$ condenser. GT $=$ gas turbine power plant. FGHX $=$ flue gas heat exchanger. $\mathrm{HRVG}=$ heat recovery vapor generator. HTFP $=$ heat transfer fluid pump. ORCP $=$ ORC pump. ORCT $=$ ORC turbine. $\mathrm{WP}=$ water pump.

\section{Figure 4. Exergy Destruction Distribution in the Compound Gas - Rankine Cycle}

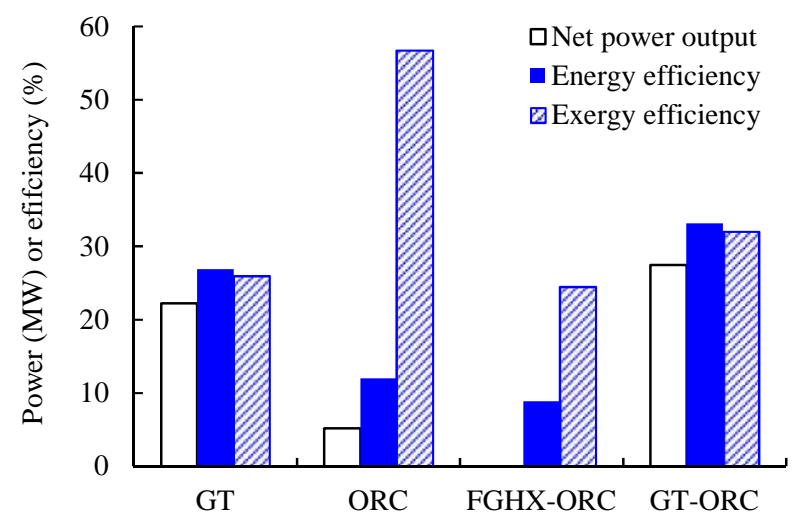

Note: $\mathrm{GT}=$ gas turbine power plant. FGHX $=$ flue gas heat exchanger. FGHX-ORC $=$ waste heat recovery system. GT-ORC $=$ compound gas - Rankine power plant. ORC = organic Rankine cycle.

Figure 5. Net Power Output, and Energy and Exergy Efficiencies of the Compound Gas - Rankine Cycle and its Sub-Systems

The T-Q diagram of heat exchange in Figure 3 reveals a good match between R245fa and the intermediate heat transfer fluid in the HRVG. However, a significant temperature difference between the intermediate heat transfer fluid and flue gas exists. This is partly attributable to R245fa's combination of both modest evaporation temperature and latent heat at the imposed maximum ORC pressure. This results in the majority of the waste heat recovery system exergy destruction occurring in the FGHX (Figure 4). The intermediate heat transfer fluid - flue gas temperature difference adversely impacts the exergy efficiency of the FGHX and therefore of the overall waste heat recovery subsystem (Figure 5). Considering the waste heat recovery subsystem alone, exergy destruction in the HRVG, condenser and turbine are comparable. For the compound gas-Rankine power cycle, most of the exergy destruction occurs in the GT cycle, which is essentially attributable to the combustion process and the difference between the combustion chamber feed air and flame temperatures.
The compound gas-Rankine cycle improves the plant net power generation output and thermal/exergy efficiency to approximately $27.4 \mathrm{MW}$ and $33 \%$, respectively. This represents approximately $23 \%$ and $6 \%$ improvement relative to the existing gas cycle.

\section{Economics of Waste Heat - Powered Electricity Generation}

The economic feasibility of supplemental electricity generation from recovered waste heat is assessed using the input economic analysis parameters listed in Table 4. Based on typical ORC capital and operating costs, and UAE subsidized industrial electricity tariffs, the net annual savings associated with electricity generation from waste heat are estimated at 1.6 million USD for the process facility considered. The payback period of the waste heat recovery system would exceed 5 years. Primary energy savings would amount 1.3 million metric standard cubic feet per day (MMSCFD) of natural gas, and avoided $\mathrm{CO}_{2}$ emissions, 457 tons of $\mathrm{CO}_{2}$ per year. 
Table 4. Economic Analysis Input Parameters for the Waste Heat Recovery System

\begin{tabular}{lc}
\hline \multicolumn{1}{c}{ Item } & Cost \\
\hline ORC CAPEX & $3,000 \mathrm{USD} / \mathrm{kW} \mathrm{[13]}$ \\
ORC O\&M & $0.013 \mathrm{USD} / \mathrm{KWh}[13]$ \\
$\mathrm{GT} \mathrm{CO}_{2}$ emission rate & $0.58 \mathrm{kgCO} / \mathrm{kWh}[14]$ \\
$\mathrm{CO}_{2}$ emission tax rate & $20 \mathrm{USD} / \mathrm{tCO} 2[15]$ \\
Electricity price & $0.042 \mathrm{USD} / \mathrm{kWh}[16]$ \\
Plant availability & $90 \%$ \\
\hline
\end{tabular}

Note: CAPEX = capital expenditure. O\&M = operating and maintenance costs. Electricity prices are subsidized average prices based on two months peak and eight months off-peak tariffs per year.

\section{Conclusions}

Using a R245fa Rankine cycle to recover waste heat from an existing industrial gas turbine power plant, an additional 5.2 MW (23\%) of net power is produced, at Rankine cycle thermal and exergy efficiencies of $12 \%$ and $57 \%$, respectively. When accounting for the heat recovery efficiency of the intermediate heat transfer loop, the thermal and exergy efficiencies of the overall waste heat recovery system are of approximately $9 \%$ and $24 \%$, respectively. Most of the exergy destruction occurs in the gas turbine cycle and intermediate flue gas heat exchanger. The combined gas-organic Rankine cycle improves the overall energy/exergy efficiency of the existing power plant by approximately $6 \%$. This is estimated to result in 1.6 million USD net annual operating cost savings, or 1.3 million metric standard cubic feet per day (MMSCFD) of natural gas primary energy savings, with 457 tons of avoided $\mathrm{CO}_{2}$ emissions per year.

\section{Acknowledgements}

The financial support of The Petroleum Institute Research Center (PIRC) grant No. 14502 is gratefully acknowledged.

\begin{tabular}{|c|c|c|c|c|c|}
\hline \multirow{4}{*}{$\begin{array}{l}A \\
C_{p}\end{array}$} & \multicolumn{5}{|c|}{ Nomenclature } \\
\hline & $=$ & surface area $\left(\mathrm{m}^{2}\right)$ & \multicolumn{3}{|c|}{ Superscript } \\
\hline & $=$ & specific heat capacity at constant pressure & $c h$ & $=$ & chemical \\
\hline & & $(\mathrm{J} / \mathrm{kg}-\mathrm{K})$ & $p h$ & $=$ & physical \\
\hline$x$ & $=$ & exergy transfer rate $(\mathrm{W})$ & & & \\
\hline$h$ & $=$ & specific enthalpy $(\mathrm{kJ} / \mathrm{kg})$ & \multicolumn{3}{|c|}{ Subscript } \\
\hline$L$ & $=$ & latent heat $(\mathrm{kJ} / \mathrm{kg})$ & air & $=$ & ambient air \\
\hline $\begin{array}{l}L H V \\
\dot{m}\end{array}$ & $=$ & lower heating value $(\mathrm{kJ} / \mathrm{kg})$ & $c$ & $=$ & critical \\
\hline$M$ & $=$ & mass flow rate $(\mathrm{kg} / \mathrm{s})$ & cond & $=$ & condenser \\
\hline$M$ & $=$ & molar mass $(\mathrm{g} / \mathrm{mol})$ & $d$ & $=$ & destroyed \\
\hline$P$ & $=$ & pressure $(\mathrm{Pa})$ & eva & $=$ & evaporation \\
\hline$P_{0}$ & $=$ & environmental dead state pressure $(\mathrm{Pa})$ & $f$ & $=$ & fuel \\
\hline$\dot{Q}$ & $=$ & heat transfer rate $(\mathrm{W})$ & $i$ & $=$ & component (i.e., species) index \\
\hline$R$ & $=$ & universal gas constant $(8.314 \mathrm{~J} / \mathrm{K}-\mathrm{mol})$ & in & $=$ & inlet \\
\hline$s$ & $=$ & specific entropy $(\mathrm{kJ} / \mathrm{kg}-\mathrm{K})$ & $\max$ & $=$ & maximum \\
\hline$T$ & $=$ & temperature $\left({ }^{\circ} \mathrm{C}\right)$ & $\operatorname{mix}$ & $=$ & mixture \\
\hline$T_{0}$ & $=$ & environmental dead state temperature $(\mathrm{Pa})$ & $n$ & $=$ & system boundary index \\
\hline$\dot{W}$ & $=$ & power $(\mathrm{W})$ & net & $=$ & net \\
\hline \multirow[t]{2}{*}{$y$} & $=$ & molar fraction $(-)$ & out & $=$ & outlet \\
\hline & & & sat & $=$ & saturation \\
\hline Greek & & & $v$ & $=$ & vapor \\
\hline$\Delta$ & $=$ & difference & $w$ & $=$ & water \\
\hline$\varepsilon$ & $=$ & heat exchanger effectiveness $(\%)$ & 0 & $=$ & environmental dead state \\
\hline$\gamma$ & $=$ & Fuel exergy grade $(-)$ & & & \\
\hline$\eta$ & $=$ & energy efficiency or isentropic efficiency (\%) & & & \\
\hline$\rho$ & $=$ & mass density $\left(\mathrm{kg} / \mathrm{m}^{3}\right)$ & & & \\
\hline$\varphi$ & $=$ & exergy efficiency $(\%)$ & & & \\
\hline
\end{tabular}

\section{References}

[1] Eveloy, V., Rodgers, P. and Popli, S., Power Generation and Cooling Capacity Enhancement of Natural Gas Processing Facilities in Harsh Environmental Conditions through Waste Heat Utilization, International Journal of Energy Research, Vol. 38, pp. 1921-1936, 2014.
[2] Chacartegui, R., Sánchez, D., Muñoz, J.M., and Sánchez, T., Alternative ORC Bottoming Cycles for Combined Cycle Power Plants, Applied Energy, Vol. 86, No. 10, pp. 2162-70, 2009. 
[3] Chan, C. W., Ling-Chin, J., Roskilly, A.P., A Review of Chemical Heat Pumps, Thermodynamic Cycles and Thermal Energy Storage Technologies for Low Grade Heat Utilization, Applied Thermal Engineering, Vol. 50, pp. 1257-1273, 2013.

[4] Arabian Gulf Process Plant. 2013.

[5] Statistics Centre of Abu Dhabi, Statistical YearbookofAbuDhabi2013https://www.abudhabi.ae/cs/g roups/public/documents/publication/ywrf/mtix/ edisp/ad 121297.pdf [accessed September 2015]

[6] Freemeteo,http://freemeteo.ae/weather/ [accessed September 2015]

[7] Yu, G., Shu, G., Tian, H., Wei, H., and Liu, L., Simulation and Thermodynamic Analysis of a Bottoming Organic Rankine Cycle (ORC) of Diesel Engine (DE), Energy, Vol. 51, pp. 281-290, 2013.

[8] Bao, J. and Zhao, L., A Review of Working Fluid and Expander Selections for Organic Rankine Cycle, Renewable and Sustainable Energy Reviews, Vol. 24, pp. 325-42, 2013.

[9] Aspentech, Version 8.4 of aspenONE Software,http://www.aspentech.com/products/aspenONE / [accessed September 2015].

[10] WST, World sea temperatures, Abu Dhabi sea temperature,2014http://worldseatemp.com/en/UAE/AbuDhabi/ [accessed September 2015].
[11] Zhu, S., Deng, K., and Qu, S., Energy and Exergy Analyses of a Bottoming Rankine Cycle for Engine Exhaust Heat Recovery, Energy, Vol. 58, pp. 448-457, 2013.

[12] Dincer, I., and Rosen, A, Exergy, Energy, Environment and Sustainable Development, Elsevier, 2nd Ed., USA, California, 2013.

[13] Jung, H.C., Krumdieck, S., and Vranjes, T., Feasibility Assessment of Refinery Waste Heat-to-power Conversion using an Organic Rankine Cycle, Energy Conversion and Management, Vol. 77, pp. 396-407, 2014.

[14] Nazari, S., Shahhoseini, O., Sohrabi-Kashani, A., Davari, S., Paydar, R., and Delavar-Moghadam, Z, Experimental Determination and Analysis of $\mathrm{CO}_{2}, \mathrm{SO}_{2}$ and $\mathrm{NO} x$ Emission Factors in Iran's Thermal Power Plants, Energy, Vol. 35, pp. 2992-2998, 2010.

[15] Pruitt, K. A., Braun, R. J., and Newman, A. M., Establishing Conditions for the Economic Viability of fuel Cell-based, Combined Heat and Power Distributed Generation Systems, Applied Energy, Vol. 111, pp. 904 920, 2013.

[16] Regulation and Supervision Bureau, New Water and Electricity Tariffs Structure, January 2015, <http://rsb.gov.ae/en/sector/new-water-and-electricitytariffs-structure> [accessed September 2015]. 